\title{
Uma resposta ao tempo
}

\section{A response to time}

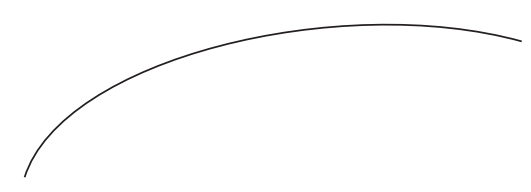

Percebe-se uma ampliação na quantidade de estudos sobre o tema do Envelhecimento Humano no segmento acadêmico. Fato relevante é o aumento do número de renomados pesquisadores se dedicando ao assunto e a consequente repercussão sobre algo antes pouco discutido em nossa sociedade.

Destaco, entre outras importantes aquisições para a área, a professora Mirian Goldenberg. Além de estar produzindo bastante, Mirian apresenta uma abordagem que vem em linha com o que partilhamos - a valorização do cidadão idoso e a busca da felicidade -, sem omitir, no entanto, as dificuldades naturais decorrentes do processo de envelhecimento, quando o cuidado deve ocorrer em fases precoces visando garantir mais anos com qualidade de vida.

Escrevi algumas palavras sobre seu mais recente livro, A bela velhice (Editora Record, 2013), e desejo partilhar com os leitores da RBGG alguns trechos de meu texto, pois é nesta direção que acreditamos que devam seguir as políticas sociais e de saúde no Brasil.

Quando escreveu A velhice, Simone de Beauvoir procurou refletir sobre a exclusão dos idosos na sociedade. Partiu do ponto de vista de quem sabia que logo se tornaria um deles, como que projetando seu próprio destino. A pensadora observou uma duplicidade nas relações entre jovens e velhos: de um lado, na maioria das vezes, o respeito à sua condição de pais ou mães; de outro, porém, uma percepção dos idosos como "seres inferiores", dos quais são suprimidas quaisquer responsabilidades e imputadas culpas pela sobrecarga de compromissos que impunham a filhos ou netos.

Beauvoir também mencionava o desamparo da terceira idade no que dizia respeito a seus recursos materiais, à desconsideração de suas opiniões e emoções e ao tratamento muitas vezes humilhante que a sociedade lhes dispensava. O que a autora francesa descreveu, em síntese, foi um cenário potencialmente cruel, em que o idoso acaba tratado como uma espécie de objeto incômodo, inútil e, no mais das vezes, desprezível. Observemos, agora, os nossos dias.

Nos últimos anos, sempre que me refiro ao perfil demográfico da sociedade brasileira, tenho por hábito descrever o Brasil como um "país jovem de cabelos brancos". As estatísticas têm demonstrado que nossa população está envelhecendo; as pesquisas mais recentes apontam que o número de idosos terá aumento significativo nos próximos 30 anos. É um dado expressivo: todo ano, 700 mil novos idosos são incorporados a esse segmento da pirâmide etária. 
O aumento da expectativa de vida é a priori um fator positivo, mas precisamos ponderar que a longevidade só será de fato uma conquista se agregarmos qualidade aos anos adicionais vividos. E não é preciso que o poder público e a sociedade transformem essa questão no dilema entre investir em jovens ou em idosos. É perfeitamente possível acolher, assistir e atender a esse contingente populacional cada vez mais numeroso sem abandonar as novas gerações.

Ao confrontarmos esses dados e as observações de Simone de Beauvoir, temos diante de nós um dos grandes desafios da atualidade: como lidar com esse fato novo, que é o início do protagonismo dos idosos? É a pergunta que Mirian Goldenberg começa a responder em seu livro, convidando-nos a refletir sobre a óbvia - embora convenientemente ignorada por alguns - constatação de que a velhice é inevitável e o envelhecimento é uma conquista a ser buscada. A expressão "bela velhice" - muito além de sua leveza poética - torna-se uma tendência, pois a sociedade perceberá gradualmente que chegar aos 85 ou mesmo aos 100 anos é algo bastante plausível nos dias de hoje. Morrer cedo é a exceção. É hora de pensarmos nesses novos tempos com a visão de uma vida ativa: fruir cada dia, amar, produzir, fazer projetos para o futuro - por que não?

Uma pessoa que se aposenta aos 60 anos precisa compreender que seu tempo de vida como "idosa" será igual ou até maior do que seus anos como trabalhadora. Teremos indivíduos se aposentando aos 60 anos e iniciando um novo ciclo de vida por mais 30 ou 40. Novas relações trabalhistas poderão se estabelecer. Essas transformações serão fantásticas e estão, na verdade, muito próximas.

Ainda é necessário fazer projeções sobre o impacto e as consequências dessas mudanças na relação entre mulheres e homens em nossa sociedade. A longevidade feminina é superior, a mulher costuma viver bem mais que seu companheiro, que, por questões culturais, costuma ser alguns anos, às vezes décadas, mais velho. Significa dizer que, em faixas etárias mais avançadas, o percentual de mulheres é bem maior que o de homens. Temos aí um novo fato: um mundo feminino. Outra característica será a observação de famílias com cinco ou seis gerações - muitas destas, possivelmente, desempregadas devido ao processo de globalização e os mais idosos do clã sendo o grande sustentáculo, pelo fato de possuírem uma aposentadoria e terem conseguido uma nova reinserção no mercado de trabalho. É assim, em linhas gerais, o cenário do novo tempo que nos espera.

Tal como Mirian Goldenberg, também desejo que seja um período muito divertido e cheio de projetos. Devemos dar risadas e olhar para essa sociedade de forma diferente daquela que hoje conhecemos, pois caminhamos para algo bem distinto, consequência do alongamento dos anos de vida. Precisamos inventar e reinventar os nossos dias. Construir algo novo, genuíno, para contemplar as características e as interessantes potencialidades desse perfil demográfico que se avizinha.

Se todos quisermos - e é certo que queremos - viver mais e com qualidade, é chegada a hora de ousar. Que a "bela velhice" seja bem-vinda! 